\title{
HUBUNGAN PENGETAHUAN SIKAP DAN KARAKTERISTIK IBU TENTANG KANKER SERVIKS DENGAN KEIKUTSERTAAN MELAKUKAN PEMERIKSAAN IVA
}

\author{
Yunita Syahputri Damanik, ${ }^{1}$ Efrata $^{2}$ \\ Institut Kesehatan DELI HUSADA Deli Tua \\ Jl.Besar No.77Deli Tua, Deli Serdang Sumatera Utara \\ Email : yunitadamanik88@gmail.com
}

\begin{abstract}
Cervical cancer is a malignant tumor that grows the area of the cervix (cervical) and is a disease caused by HPV or Human Papilloma Virus. One of the measures for early detection of cervical cancer is by screening IVA (Visual Inspection Acetic Acid). The purpose of this study was to determine the relationship of knowledge, attitude and characteristic mother of cervical cancer by doing IVA participation. The design of this study is to use a Cross Sectional. The number of samples in this study were as many as 95 people, with a sampling technique using purposive sampling. From the analysis it was found that there are six variables that have a relationship $(<0.05)$, including $p$-value education by 0:01, the frequency is married with a $p$-value of $0: 00$, sexual activity with a $p$-value of 0:01, with a p-value knowledge 0:00 and the $p$-value 0:00 while variable that does not have a relationship ( $>0.05$ ) among age with $p$-value $0: 21$, work with a $p$-value 0.79 , the frequency of pregnancy with a $p$-value 0:39 and smoking with a p-value of 0:07. From the results of multivariate analysis showed that sexual activity had a meaningful relationship with the participation of IVA examination with p-value OR $30810: 04$ and value. Expected to health professionals to provide information about the dangers of cervical cancer and the importance of conducting the examination IVA.
\end{abstract}

Keywords: Knowledge, Attitude, maternal characteristics, participation did IVA

\section{Pendahuluan}

Kanker Serviks adalah tumor ganas yang tumbuh didaerah leher rahim (serviks), yang terdapat pada daerah organ reproduksi wanita dan terletak antara rahimdengan lubang vagina menuju rahim (As' adi, 2011). Penyebab Kanker Servik adalah HPV atau Human Papilloma Virus, dengan presentase yang cukup tinggi sehingga menyebabkan Kanker Serviks, sekitar 99,7\%. Setiap satu wanita meninggal per jam di Indonesia disebabkan oleh Kanker Serviks. Jutaan wanita di dunia terinfeksi virus HPV, hal ini merupakan fakta yang nyata. Penyakit ini umumnya dianggap terjadi melalui hubungan seks (Adi, 2012).
Kanker Serviks adalah penyebab kematian nomor dua didunia pada kaum wanita dari semua penyakit kanker yang ada. Menurut WHO, terdapat 493.243 orang penderita Kanker Serviks didunia setiap tahunnya dengan jumlah angka kematian sebanyak 273. 505 orang per tahun. Wanita meninggal disebabkan Kanker Serviks per dua menit. (Emilia dkk, 2010).

Di beberapa Negara yang sedang berkembang dengan penghasilan menengah dalam lima tahun terakhir secara global telah terdiagnosis sebanyak 1.401 .400 kasus. Angka kejadian Kanker Serviks setiap tahunnya, adalah sekitar 15.000 kasus. Sedangkan jumlah angka kematiannya diperkirakan sekitar 7. 500 
kasus per tahun. Pada tahun 2001, kasus terbaru kanker serviks berjumlah 2. 429 atau lebih kurang 25, 91\% dari begitu banyak kanker yang ditemukan di Indonesia. Kanker Serviks berada diurutan kedua setelah $\mathrm{Ca}$, Mamay pada wanita. (Wijaya, 2010).

Data jumlah penderita Kanker Serviks dari Dinas Kesehatan Provinsi Sumatera pada tahun 2001 adalah sejumlah 683 kasus. Data RS dr. Pirngadi Medan tahun 2005 sebanyak 98 kasus. Data dari RSUP. Haji Adam Malik Medan penderita KLR tahun 2007 (215 kasus) (Melva, 2008).

Cara yang paling mudah untuk mendeteksi dini kanker servik adalah dengan melakukan pemeriksaan IVA (Inpeksi Visual Asam Asetat) pemeriksaan dilakukan dengan cara mengamati langsung serviks yang sebelumnya telah dioles dengan larutan asam asetat 3 hingga 5 persen. Pemeriksaan IVA telah terbukti dapat menjadi metode alternatif selain Pap Smear untuk deteksi dini Kanker Serviks (Emilia dkk, 2010).

Pemeriksaan ini dapat mendeteksi sampai 90\% korban Kanker Serviks secara akurat dan dengan biaya yang murah. Sehingga, jumlah korban akibat Kanker Serviks dapat menurun sampai lebih dari 50\% (Manan, 2011).

Penelitian lain yang terkait dalam mendukung penelitian ini adalah dilakukan oleh Indarwati tahun 2012 meneliti tentang Hubungan Pengetahuan Ibu Tentang Kanker Serviks Dengan Keikutsertaan wanita yang Melakukan IVA Test Di Kelurahan Jebres Surakarta didapat hasil yaitu: keikutsertaan ibu melakukan pemeriksaan IVA paling banyak dilakukan oleh responden dengan pengetahuan tinggi dan paling sedikit dilakukan oleh responden yang berpengetahuan rendah.

Berdasarkan survey pendahuluan yang dilakukan di Klinik Bersalin Kasih Ibu yang diwawancarai mengenai Kanker Serviks dan pemeriksaan IVA secara acak hanya 2 orang ibu yang mengetahui tentang Kanker Serviks dan Pap smear, 2 orang mengetahui tentang Kanker Serviks tetapi tidak mengetahui Pap smear, dan 1 orang tidak mengetahui Kanker Serviks dan pap smear.

Berdasarkan data yang diperoleh di Klinik Bersalin Kasih Ibu Tersebut sebanyak 2 orang ibu pernah menderita Kanker Serviks.

Berdasarkan uraian tersebut peneliti tertarik melakukan penelitian mengenai hubungan pengetahuan Ibu tentang Kanker Serviks dengan keikutsertaan melakukan pemeriksaan IVA.

\section{METODE PENELITIAN}

Jenis penelitian ini adalah survey yang bersifat deskriptif analitik dengan desain Cross Sectional yaitu suatu penelitian untuk mempelajari dinamika korelasi antara beberapa faktor risiko dengan efek, yaitu dengan cara melakukan pendekatan, observasi dan pengumpulan data secara bersamaan (point time approach).

Penelitian ini bertujuan untuk mengetahui hubungan pengetahuan, sikap dan karakteritik ibu tentang kanker serviks dengan keikutsertaan melakukan IVA di Klinik Bersalin Kasih Ibu Delitua Tahun 2015. Desain penelitian ini adalah dengan menggunakan Cross Sectional. Jumlah sampel dalam penelitian ini adalah sebanyak 95 orang, dengan teknik pengambilan sampel menggunakan purposive sampling.

Kriteria inklusi pada penelitian ini adalah responden yang sudah menikah dan masih aktif dalam aktivitas seksual dengan usia minimal 20 tahun, pendidikan akhir minimal SMA, tidak sedang hamil, tidak sedang masa nifas dan bersedia dijadikan sampel penelitian. Kriteria eksklusi pada penelitian ini adalah wanita atau ibu yang sudah menikah tetapi tidak aktif dalam aktivitas seksual dan berusia dibawah 20 tahun.

\section{HASIL PENELITIAN}

Tabel 1. Proporsi Variabel Penelitian

\begin{tabular}{ccc}
\hline Variabel & F & \% \\
\hline Pengetahuan & & \\
Tinggi & 67 & $70.5 \%$ \\
Rendah & 28 & $29.5 \%$ \\
\hline Sikap & &
\end{tabular}




\begin{tabular}{|c|c|c|}
\hline Baik & 59 & $62.1 \%$ \\
\hline Kurang & 36 & $37.9 \%$ \\
\hline \multicolumn{3}{|l|}{ Umur } \\
\hline$<35$ tahun & 49 & $51.6 \%$ \\
\hline$>35$ tahun & 46 & $48.4 \%$ \\
\hline \multicolumn{3}{|l|}{ Pendidikan } \\
\hline PT & 25 & $26.3 \%$ \\
\hline SMA & 70 & $73.7 \%$ \\
\hline \multicolumn{3}{|l|}{ Pekerjaan } \\
\hline Bekerja & 77 & $81.1 \%$ \\
\hline Tidak Bekerja & 18 & $18.9 \%$ \\
\hline \multicolumn{3}{|l|}{ Frekuensi menikah } \\
\hline 1 orang & 88 & $92.6 \%$ \\
\hline$>1$ orang & 7 & $7.4 \%$ \\
\hline \multicolumn{3}{|l|}{ Aktivitas seksual } \\
\hline$\leq 16$ tahun & 26 & $27.4 \%$ \\
\hline$\geq 20$ tahun & 69 & $72.6 \%$ \\
\hline \multicolumn{3}{|l|}{ Frekuensi Kehamilan } \\
\hline 1 kali & 6 & $6.3 \%$ \\
\hline$>1$ kali & 89 & $93.7 \%$ \\
\hline \multicolumn{3}{|l|}{ Merokok } \\
\hline Rutin & 6 & $6.3 \%$ \\
\hline Tidak & 89 & $93.7 \%$ \\
\hline \multicolumn{3}{|l|}{ Keikutsertaan IVA } \\
\hline Aktif & 55 & $57.9 \%$ \\
\hline Tidak Aktif & 40 & $42.1 \%$ \\
\hline
\end{tabular}

Dari Tabel 1 diketahui diketahui bahwa sebagian besar responden berpengetahuan tinggi $(70.5 \%)$, lebih dari separuh $(62.1 \%)$ responden memiliki sikap baik tentang kanker serviks. Sebagian besar responden berusia $<35$ tahun sebanyak (51.6 $\%)$, mayoritas berpendidikan SMA sebanyak (73.7 \%) dan mayoritas bekerja (81.1\%). Frekuensi menikah responden yang menikah dengan satu orang paling banyak yaitu (92.6 $\%)$. Lebih dari separuh $(72.6 \%)$ reponden melakukan aktivitas seksual diatas usia 20 tahun dan memiliki frekuensi kehamilan (93.7 $\%)$. Responden yang tidak rutin merokok sebanya $(93.7 \%)$ responden. Sebanyak (57.9 $\%)$ masih aktif melakukan pemeriksaan IVA.

Tabel 2. Hubungan antara Pengetahuan, Sikap,

\begin{tabular}{lcc}
\multicolumn{3}{c}{ dan Karakteristik Ibu } \\
\hline \multicolumn{1}{c}{ Variabel } & Kategori & Nilai $p$ \\
\hline Pengetahuan & Rendah & 0.006 \\
Sikap & Kurang & 0.000 \\
Umur & $>35$ & 0.16 \\
Pendidikan & PT & 0.010 \\
\hline
\end{tabular}

\begin{tabular}{lcc}
\hline Pekerjaan & Tidak Bekerja & 0.75 \\
Frekuensi Menikah & $>1$ Orang & 0.356 \\
Aktivitas Seksual & $\leq 16$ tahun & 0.010 \\
Frekuensi Kehamilan & 1 kali & 0.192 \\
Merokok & Rutin & 0.079 \\
\hline
\end{tabular}

Dari hasil analisis didapatkan bahwa terdapat 6 variabel yang mempunyai hubungan $(<0.05)$ diantaranya pendidikan dengan $\mathrm{p}$-value 0.01 , frekuensi menikah dengan $p$-value 0.00 , aktivitas seksual dengan $p$-value 0.01 , pengetahuan dengan $p$-value 0.00 dan dengan $p$-value 0.00 sedangkan variabel yang tidak mempunyai hubungan $(>0.05)$ diantaranya umur dengan $\mathrm{p}$-value 0.21 , pekerjaan dengan $\mathrm{p}$-value 0.79 , frekuensi kehamilan dengan $\mathrm{p}$ value 0.39 dan merokok dengan $p$-value 0.07 .

Tabel 3. Hasil uji regresi logistik hubungan Pengetahuan, Sikap dan Karakteristik Ibu Tentang Kanker Serviks Dengan Keikutseraan Melakukan Pemeriksaan IVA

\begin{tabular}{|c|c|c|c|c|c|c|}
\hline No & Variabel & B & SE & P-value & OR & CI (95\%) \\
\hline 1 & $\begin{array}{l}\text { Aktivitas } \\
\text { Seksual }\end{array}$ & 1.125 & .553 & .04 & 2.820 & $1.049-7.577$ \\
\hline 2 & Pendidikan & 1.037 & 0.504 & .04 & 2.820 & $1.049-7.577$ \\
\hline
\end{tabular}

Berdasarkan tabel diatas dari hasil uji regresi logistik menunjukkan bahwa variabel aktivitas seksual memiliki nilai $\mathrm{p}$-value paling kecil yaitu $p=0.042 \quad(<p=0,05)$ dan $O R$ $=3.081 ; \quad 95 \% \mathrm{CI}=1.043-9.103$, sedangkan variabel lain seperti pendidikan nilai $p=0,999$, sikap nilai $p=0,99(p>0,05)$. Dari hasil analisis multivariate didapatkan hasil bahwa aktivitas seksual mempunyai hubungan yang bermakna dengan keikutsertaan melakukan pemeriksaan IVA dengan $\mathrm{p}$-value 0.04 dan nilai OR 3.081.

\section{PEMBAHASAN}

I. Hubungan Usia dengan keikutsertaan melakukan pemeriksaan IVA

Berdasarkan analisis bivariat dengan uji chi square menunjukkan bahwa variabel usia tidak mempunyai hubungan bermakna dengan tindakan pemeriksaan IVA dengan $p=0,213$ 
dimana nilai $\mathrm{p}>0,05$. Dapat disimpulkan bahwa variabel usia tidak berhubungan dengan tindakan pemeriksaaan IVA di Klinik Bersalin Kasih Ibu Delitua Tahun 2014.

Hasil penelitian yang dilakukan Cut Nurhazanah (2008), juga sejalan yang menyatakan bahwa tidak ada hubungan yang bermakna antara kelompok usia dengan pemeriksaan IVA $(P=0,92)$ dan penelitian Darnindro dkk (2006) mendapatkan hasil bahwa tidak ada hubungan bermakna antara umur dengan pemeriksaan IVA.

\section{Hubungan pendidikan dengan keikutsertaan melakukan pemeriksaan IVA}

Berdasarkan hasil analisis bivariat dengan chi square diketahui nilai $P$ value $=0,017$ dimana $p<0,05$, hal ini menunjukkan bahwa ada hubungan yang bermakna antara tingkat pendidikan dengan pemeriksaaan IVA di Klinik Bersalin Kasih Ibu Delitua Tahun 2014. Namun setelah dilakukan uji statistik dengan regresi logistik ganda (Tabel 3) didapatkan bahwa tingkat pendidikan tidak mempunyai hubungan bermakna dengan tindakan pemeriksaan IVA, dimana pValue $=0,999(p>0,05)$.

Darnindro dkk (2006), juga melakukan penelitian terkait hal ini yang dilakukan di Rumah Susun Klender Jakarta yaitu tentang Pengetahuan Sikap Perilaku Wanita yang telah Menikah Mengenai IVA dan Faktor-Faktor yang memiliki hubungan, penelitian ini menyatakan bahwa pendidikan tidak memiliki hubungan secara bermakna dengan IVA. Namun beberapa hasil penelitian lain justru mendapat hasil yang berbeda dengan penelitian ini, antara lain : penelitian yang dilakukan oleh Sakanti (2007) menyatakan bahwa ada hubungan pendidikan mempunyai secara bermakna dengan pemeriksaan IVA.

\section{Hubungan pekerjaan dengan keikutsertaan melakukan pemeriksaan IVA}

Dari hasil uji Chi-square menunjukkan bahwa variabel pekerjaan tidak mempunyai hubungan bermakna dengan pemeriksaan IVA dengan $p$-value $0.798(>0,05)$. Sejalan dengan penelitian yang dilakukan Jamsiah di Selangor Malaysia tahun 2009, uji statistik menunjukkan tidak ada hubungan antara pekerjaan dengan keikutsertaan melakukan pemeriksaan IVA.

Pada penelitian ini tingkat pemeriksaan IVA lebih besar didapatkan pada kelompok responden yang bekerja, dapat disimpulkan dari hasil penelitian ini bahwa pekerjaan tidak ada hubungan dengan tindakan pemeriksaan IVA. Sejalan dengan penelitian Wirawan (2001) menyatakan bahwa responden yang bekerja lebih banyak melakukan pemeriksaan IVA daripada responden yang tidak bekerja.

\section{Hubungan frekuensi menikah dengan keikutsertaan melakukan pemeriksaan IVA}

Dari hasil uji Chi-square menunjukkan bahwa variabel frekuensi menikah mempunyai hubungan bermakna dengan pemeriksaan IVA dengan $\mathrm{p}$-value $0.002(<0,05)$. Hasil penelitian ini didukung oleh penelitian Suprijono (2008) yang menyebutkan bahwa presentase pernikahan yang terbanyak adalah menikah dengan frekuensi $1 x$ yaitu 118 orang (98.3\%) dan menikah dengan frekuensi $2 x$ yaitu sejumlah 2 orang $(1,7 \%)$, dimana dalam penelitian ini frekuensi menikah mempunyai hubungan dengan keikutsertaan dalam melaukan pemeriksana IVA

Pada beberapa hasil penelitian yang pernah dilakukan diperoleh bahwa wanita yang telah menikah lebih dari 1 kali akan meningkatkan risiko kanker leher rahim (serviks) sebesar 1,99 kali dan 1,5 kali, sedangkan jika pasangan seksualnya lebih dari 4 maka risikonya yaitu 3,6 kali.

\section{v. Hubungan Aktivitas Seksual Dengan Keikutsertaan Pemeriksaan IVA \\ Dari hasil uji Chi-square menunjukkan} bahwa variabel aktivitas seksual mempunyai hubungan bermakna dengan pemeriksaan IVA 
dengan p-value $0.010(<0,05)$. Hasil penelitian ini mendukung hasil penelitian yang telah dilakukan oleh Khasbiyah (2004) penelitian tersebut menunjukkan bahwa $74 \%$ penderita kanker serviks di RS Dokter Kariadi Semarang melakukan hubungan seksual pertama kali di bawah umur 20 tahun, hal ini juga didukung oleh penelitian Melva (2008) yang menyebutkan bahwa $60 \%$ penderita kanker serviks adalah mereka yang berhubungan seks pertama kali pada umur < 20 tahun. Umur saat perkawinan $\leq 20$ tahun erat kaitanya dengan aktivitas seksual.

\section{Hubungan frekuensi dengan keikutsertaan pemeriksaan IVA}

Dari hasil uji Chi-square menunjukkan bahwa variabel frekuensi kehamilan mempunyai hubungan bermakna dengan pemeriksaan IVA dengan p-value $0.396(>0,05)$. Hasil penelitian ini didukung oleh penelitian Suprijono (2008) yang menyebutkan bahwa presentase pernikahan yang terbanyak adalah menikah dengan frekuensi $1 x$ yaitu 118 orang (98.3\%) dan menikah dengan frekuensi $2 x$ yaitu sejumlah 2 orang $(1,7 \%)$, dimana dalam penelitian ini frekuensi menikah mempunyai hugungan dengan keikutsertaan dalam melaukan pemeriksana IVA

Penelitian di Bali tahun 2000 menunjukkan $32 \%$ penderita kanker serviks ditemukan pada saat paritas lebih dari empat. Peneliti lain juga mengatakan bahwa paritas yang lebih dari tiga mengakibatkan naiknya frekuensi kanker serviks menjadi 3 kali, multiparitas juga berkaitan dengan usia menikah yang umumnya ditemukan pada usia muda.

\section{Hubungan merokok dengan keikutsertaan pemeriksaan IVA melakukan}

Dari hasil uji Chi-square menunjukkan bahwa variabel merokok tidak mempunyai hubungan yang bermakna dengan pemeriksaan IVA dengan p-value $0.079(<0,05)$. Namun setelah dilakukan analisis statistik dengan uji regresi logistik ganda (Tabel 20 ) diperoleh hasil bahwa variabel merokok tidak berhubungan secara bermakna dengan pemeriksaan IVA dengan nilai $P$-value $=0,352$.

Hasil penelitian ini sejalan dengan Suliani (2008) mengenai faktor-faktor risiko yang berhubungan dengan keikutsertaan melakukan pemeriksaan IVA dengan kebiasaan merokok, dimana dalam penelitian ini tidak ada hubungan yang bermakna antara kebiasaan merokok dengan kebiasaann untuk memeriksakan diri untuk IVA.

\section{VIII.Hubungan pengetahuan dengan keikutsertaan melakukan pemeriksaan IVA}

Hasil uji Chi-square menunjukkan bahwa variabel pengetahuan mempunyai hubungan bermakna dengan pemeriksaan IVA dengan $P$ value $=0,006 \quad(p<0,05)$. Berdasarkan hasil analisis statistik dengan uji regresi logistik ganda (Tabel 20) diperoleh hasil bahwa variabel pengetahuan tidak berhubungan secara bermakna dengan pemeriksaan IVA, dimana $P$ value $0,999(p>0,05)$. Dengan hasil tersebut dapat disimpulkan bahwa pengetahuan tidak memiliki hubungan kuat dengan tindakan pemeriksaan IVA pada penelitian ini.

Hasil penelitian ini berbeda dengan hasil penelitian yang dilakukan oleh Moegni (2005) di poliklinik RSUP CM Jakarta, dengan hasil yang diperoleh hanya 2,9\% responden yang memiliki pengetahuan baik mengenai pemeriksaan pap smear sedangkan responden yang memiliki pengetahuan cukup sebesar $21,6 \%$ dan yang berpengetahuan kurang sebesar 75,5\%. Rendahnya tingkat pengetahuan masyarakat mengenai pentingnya pemeriksaan IVA di Indonesia cukup banyak disebabkan oleh kurangnya tingkat kewaspadaan masyarakat terhadap kanker serviks serta informasi mengenai cara pencegahan dan deteksi dininya. 


\section{Hubungan}

Keikutsertaan

Pemeriksaan IVA

Sikap

Hasil uji Chi-square menunjukkan bahwa variabel sikap berhubungan secara bermakna dengan pemeriksaan IVA di Klinik Bersalin Kasih Ibu Delitua Tahun 2015 dengan $P$ value $=0,000(p<0,05)$.

Hasil penelitian ini sejalan dengan penelitian Yuniasih (2012) di Puskesmas Kuta Utara yaitu sikap usia subur sangat mempengaruhi pelaksanaan pemeriksaan IVA. Sejalan pula dengan penelitian yang dilakukan Darnindro (2006) di Jakarta bahwa terdapat hubungan yang signifikan antara sikap responden dengan pemeriksaan IVA.

\section{KESIMPULAN}

1. Ada hubungan yang signifikan antara pengetahuan dengan keikutsertaan ibu dalam melakukan pemeriksaan IVA di Klinik Bersalin Kasih Ibu Delitua tahun 2015

2. Ada hubungan yang signifikan antara sikap dengan keikutsertaan ibu dalam melakukan pemeriksaan IVA di Klinik Bersalin Kasih Ibu Delitua tahun 2015

3. Tidak ada hubungan yang signifikan antara usia dengan keikutsertaan ibu dalam melakukan pemeriksaan IVA di Klinik Bersalin Kasih Ibu Delitua tahun 2015

4. Ada hubungan yang signifikan antara pendidikan dengan keikutsertaan ibu dalam melakukan pemeriksaan IVA di Klinik Bersalin Kasih Ibu Delitua tahun 2015

5. Tidak ada hubungan yang signifikan antara pekerjaan dengan keikutsertaan ibu dalam melakukan pemeriksaan IVA di Klinik Bersalin Kasih Ibu Delitua tahun 2015

6. Ada hubungan yang signifikan antara frekuensi menikah dengan keikutsertaan ibu dalam melakukan pemeriksaan IVA di Klinik Bersalin Kasih Ibu Delitua tahun 2015

7. Ada hubungan yang signifikan antara aktivitas seksual dengan keikutsertaan ibu dalam melakukan pemeriksaan IVA di Klinik Bersalin Kasih Ibu Delitua tahun 2015
8. Tidak ada hubungan yang signifikan antara frekuensi kehamilan dengan keikutsertaan ibu dalam melakukan pemeriksaan IVA di Klinik Bersalin Kasih Ibu Delitua tahun 2015

9. Tidak ada hubungan yang signifikan antara merokok dengan keikutsertaan ibu dalam melakukan pemeriksaan IVA di Klinik Bersalin Kasih Ibu Delitua tahun 2015

\section{DAFTAR PUSTAKA}

Arikunto, Suharsimi (2006), Prosedur Penelitian Suatu Pendekatan Praktik, PT. Rineka Cipta, Jakarta.

Emilia, Ova, dkk (2010), Bebas Ancaman Kanker Serviks, MedPress, Yogyakarta.

Evennett, Karen (2004), Pap Smear: Apa Yang Perlu Anda Ketahui?, Arcan, Jakarta.

Huda, Aghia, Gina. 2011. Gambaran Pengetahuan Ibu Tentang Kanker Serviks Dan Pemeriksaan IVA Di Kelurahan Cempaka Tahun 2011 Serta Faktor-Faktor Yang Berhubungan. Jakarta: tidak dipublikasikan

Indarwati. 2012. Hubungan Pengetahuan Ibu Tentang Kanker Serviks Dengan Keikutsertaan Ibu Melakukan IVA Test Di Kelurahan Jebres Surakarta. Jurnal Kesehatan STIKes Aisyiyah Surakarta, Agustus 2012. Vol 9 No 2

Kumalasari, Intan dkk (2013), Kesehatan Reproduksi, Salemba Medika, Jakarta.

Lestadi, Julisar (2009), Sitologi Pap Smear: Alat Pencegahan Dan Deteksi Dini Kanker Leher Rahim, EGC, Jakarta

M. Manan, El (2011), Miss V, BukuBiru, Yogyakarta.

Melva. 2008. Faktor-Faktor Yang Mempengaruhi Kejadian Kanker Leher Rahim Pada Penderita Yang Datang Berobat Di Rsup H. Adam Malik Medan Tahun 2008. http://grahacendikia.wordpress.com

Muhammad, As'adi (2011), Tips Jitu Bisa Hamil, BukuBiru, Yogyakarta. 
Notoatmodjo, Soekidjo (2007), Kesehatan Masyarakat: IImu dan Seni, Rineka Cipta, Jakarta.

(2010), Metodologi Penelitian Kesehatan, Rineka Cipta, Jakarta.

NS, Sallika (2010), Serba Serbi Kesehatan Perempuan, Bukune, Jakarta.

Nursalam (2011), Konsep dan Penerapan Metodologi Penelitian IImu Keperawatan, Salemba Medika, Jakarta.

Rozi, F. M (2013), Kiat Mudah Mengatasi Kanker Serviks, Aulia Publishing, Yogyakarta.

Sastrosudarmo, Wh (2010), Kanker The Silent Killer, Garda Media, Jakarta.

Shadine, Mahannad (2012), Penyakit Wanita: Pencegahan, Deteksi Dini dan 